\title{
PELUANG PEMILIKAN PERUMAHAN GRIYA PESONA ASRI DI KECAMATAN SIDOHARJO SRAGEN JAWA TENGAH
}

\author{
Unggul Priyadi dan Fathya Rahmadhani Zainuri ${ }^{2}$ \\ ${ }^{1,2}$ Fakultas Ekonomi, Universitas Islam Indonesia \\ Email : priyadi.unggul@gmail.com
}

\begin{abstract}
ABSTRAK
Sidoharjo Sragen adalah pintu gerbang masuk ke Ibukota Kabupaten Sragen. Begitu banyak akses dari para pedagang yang lewat di Kabupaten penyebab Sidoharjo dari meningkatnya permintaan untuk rumah dan juga mendorong para pengembang untuk membangun perumahan. Hal ini juga terjadi untuk Griya Pesona Asri yang terletak di gerbang Sragen. Penelitian ini bertujuan untuk menganalisis pengaruh harga perumahan, pendapatan comsumer, fasilitas, dan jenis pekerjaan terhadap peluang pembelian perumahan di Griya Pesona Asri.

Alat analisis yang digunakan adalah LPM (Linear Probability Model) regresi. Responden dalam penelitian ini adalah warga Griya Pesona Asri. Hasil penelitian menunjukkan bahwa harga perumahan yang memberikan efek yang signifikan dan negatif terhadap peluang pembelian rumah sederhana atau selain sederhana di Griya Pesona Asri. Pendapatan dari pelanggan memiliki efek negatif dan signifikan terhadap peluang pembelian rumah sederhana atau selain sederhana di Griya Pesona Asri.
\end{abstract}

Kata kunci: LPM, Perumahan Pembelian Peluang, Griya Pesona Asri

\section{ABSTRACT}

Sidoharjo Sragen is the entrance gate to the Capital District of Sragen. So many Access of the traders passing by in the district of sidoharjo cause of the increasing demand for houses and it also encourages the developers to build housing. This also happens to Griya Pesona Asri which is located at the gate of Sragen. This research is aimed to analyze the influence of housing price, comsumer income, facilities, and the types of jobs towards the opportunities of housing purchase in Griya Pesona Asri.

The analytical tool which is used is LPM (Linear Probability Model) regression. The respondents in this study are the residents of Griya Pesona Asri. The results show that the price of the housing gives significant and negative effects towards the modest housing purchase opportunities or the other than modest in Griya Pesona Asri. The income of the customers has negative effect and significant on the modest housing purchase opportunities or the other than modest in Griya Pesona Asri.

Keywords: LPM, Housing Purchase Opportunities, Griya Pesona Asri 


\section{PENDAHULUAN}

Kebutuhan rumah merupakan salah satu kebutuhan dasar manusia setelah pangan dan sandang. Setiap individu mengutamakan pemenuhan kebutuhan dasar daripada kebutuhan sekundernya. Menurut UU No 4 Tahun 1992 pasal 5 ayat (1) tentang perumahan dan pemukiman bahwa setiap warga negara mempunyai hak untuk menempati dan/atau menikmati dan/atau memiliki rumah yang layak dalam lingkungan yang sehat, aman, serasi, dan teratur. Dengan demikian setiap individu mempunyai banyak pilihan dalam menentukan perumahan atau pemukiman.

Pilihan tersebut bisa membangun sendiri ataupun menyewa, membayar dengan kredit atau tunai, dan hibah atau dengan cara lain seperti yang diatur oleh undang-undang yang berlaku.Dewasa ini banyak berkembang berbagai jenis rumah dari yang modern, seperti apartemen dan kondominium sampai jenis yang sederhana, seperti rumah susun sederhana dan rumah biasa. Berkembangnya jenis perumahan juga menyebabkan naiknya permintaan akan rumah. Karena adanya pertambahan penduduk dari waktu ke waktu. Seiring dengan berkembangnya gaya hidup masyarakat moderen yang dinamis, serta lebih cenderung untuk memiliki rumah dengan cara yang mudah, aman, dan cepat. Hal ini merupakan poin penting bagi para pengembang properti untuk membangun dan mengembangkan perumahan guna memenuhi kebutuhan masyarakat akan suatu tempat tinggal.

Kabupaten Sragen memiliki luas wilayah $941.55 \mathrm{Km}^{2}$ yang terbagi dalam 20 kecamatan, 8 kelurahan, dan 208 desa. Memiliki jumlah penduduk sebesar 896.201 jiwa yang terdiri dari laki-laki sebanyak 444.003 jiwa dan perempuan sebanyak 452.198 jiwa dengan angka ratio jenis kelamin 982. Dengan luas wilayah 941.55 $\mathrm{Km}^{2}$ maka kepadatan penduduk mencapai sebesar 952/Km². Pertumbuhan penduduk
Kabupaten Sragen mengalami peningkatan jumlah penduduk dari tahun 2009 sampai 2013 dari 877.402 jiwa ke 896.201 yaitu sebesar 18.799 jiwa. Hal ini mendorong munculnya perumahan-perumahan baru untuk mencukupi permintaan perumahan yang didorong dari pertumbuhan penduduk yang meningkat. Terlebih di Kecamatan Sidoharjo yang terletak sebagai pintu gerbang masuk lbu Kota Kabupaten Sragen.Melihat letak Kecamatan Sidoharjo yang berada di gerbang pintu masuk kota Sragen menyebabkan banyaknya akses aktivitas para pedagang berlalu lalang. Hal ini menyebabkan permintaan akan rumah di Kecamatan Sidoharjo meningkat, serta mendorong pengembang untuk membangun perumahan, seperti salah satunya perumahan Griya Pesona Asri.Griya Pesona Asri merupakan perumahan real estate (satu pintu) yang mempunyai 64 unit perumahan yang terdiri dari tipe 45, 60, 90, dan 100 . Pada tipe perumahan 45 terdapat 46 unit perumahan, tipe 60 terdapat 5 unit perumahan, tipe 90 sebanyak 7 unit, dan tipe 100 sebanyak 6 unit. Griya Pesona Asri merupakan perumahan terbesar di Kecamatan Sidoharjo. Hal ini menarik untuk diteliti mengenai "Peluang Pemilikan Rumah Griya Pesona Asri di Kecamatan Sidoharjo Sragen Jawa Tengah".

Berdasarkan uraian latar belakang di atas dibuat rumusan masalah sebagai berikut :

1. Apa yang menjadi latar belakang masyarakat dalam membeli perumahan sederhana di Griya Pesona Asri ?

2. Bagaimana faktor harga perumahan, pendapatan konsumen, fasilitas, dan jenis pekerjaan dalam mempengaruhi peluang pemilikan perumahan sederhana di Griya Pesona Asri ?

\section{Tujuan Penelitian}

1. Untuk menganalisis latar belakang konsumen dalam memutuskan 
pemilikan perumahan sederhana di Griya Pesona Asri.

2. Untuk menganalisis faktor-faktor yang mempengaruhi peluang pemilikan perumahan sederhana di Griya Pesona Asri.

\section{TINJAUAN PUSTAKA}

\section{Teori Permintaan}

Banyak teori yang membahas tentang teori permintaan, karena permintaan sangat mempengaruhi jumlah output yang akan dihasilkan ketika harga besifat kaku. Karena permintaan ini akan mempengaruhi perekonomian jangka pendek, para ahli ekonomi mempelajari teori permintaan dan faktor-faktor yang mempengaruhi permintaan, yang berguna dalam menstabilakan ekonomi jangka pendek. Serta ada beberapa faktor yang mempengaruhinya yaitu : harga, pendapatan konsumen, jumlah konsumen, selera konsumen, dan ramalan mengenai keadaan dimasa yang akan datang. (Mankiw 2003)

\section{BIAYA PELUANG}

Biaya peluang yaitu biaya yang kita keluarkan atau kita korbankan untuk memperoleh sesuatu. Biaya bisa merupakan pengeluaran berbentuk uang atau hal lain yang berkaitan langsung dengan uang. (Case dan Fair 2002)

\section{HUKUM PERMINTAAN}

Hukum permintaan berbunyi ketika harga suatu barang meningkat, maka jumlah permintaan akan menurun, dan ketika harganya turun, maka jumlah permintaan akan naik.

\section{KATEGORISASI PERUMAHAN}

Berdasarkan ukuran perumahan dapat dikategorikan menjadi bebrapa jenis, yaitu :

a. Luas kapling rumah besar : $120 \mathrm{~m}^{2}$ $600 \mathrm{~m}^{2}$ (tipe 70)

b. Luas kapling rumah sedang : $70 \mathrm{~m}^{2}-$ $100 \mathrm{~m}^{2}$ (tipe 45-54) c. Luas kapling rumah kecil : $21 \mathrm{~m}^{2}-54$ $\mathrm{m}^{2}$ (tipe 21-36)

\section{HIPOTESIS}

a. Harga rumah diduga berpengaruh signifikan terhadap peluang pemilikanrumah Griya Pesona Asri di Kecamatan Sidoharjo Sragen.

b. Pendapatan konsumen berpengaruh signifikan terhadap peluang pemilikanrumahGriya Pesona Asri di Kecamatan Sidoharjo Sragen.

c. Fasilitas diduga berpengaruh signifikan terhadap peluang pemilikanrumahGriya Pesona Asri di Kecamatan Sidoharjo Sragen.

d. Jenis pekerjaan diduga berpengaruh signifikan terhadap peluang pemilikanrumahGriya Pesona Asri di Kecamatan Sidoharjo Sragen.

\section{METODE PENELITIAN Jenis Penelitian}

Jenis data yang digunakan dalam penelitian ini yaitu kualitatif dan sumber data yang digunakan adalah primer dengan menggunakan pendekatan cross sectional dimana data variabel bebas dan terikat diambil pada waktu yang bersamaan untuk mengetahui hubungan kedua variabel tersebut.

\section{Tempat dan Waktu Penelitian}

Data penelitian ini nantinya diambil dari warga yang tinggal di perumahan Griya Pesona Asri Kecamatan Sidoharjo Sragen. Data diambil pada bulan Juli 2015.

\section{Metode dan Teknik Pengumpulan Data}

Lokasi penelitian di perumahan Griya Pesona Asri Kecamatan Sidoharjo, Kabupaten Sragen. Data yang digunakan merupakan data primer yang langsung diperoleh dari seluruh obyek penelitian (metode sensus). Respondennya adalah penduduk Perumahan Griya Pesona Asri. Dalam pengumpulan data agar memperoleh 
data yang lebih lengkap dan dapat dipertanggung jawabkan keaslian dan kebenarannya, dilakukan dengan observasi serta melakukan wawancara dengan menggunakan kuesioner.

\section{Variabel Penelitian}

Variabel dalam penelitian ini meliputi varibel dependen dan variabel independen. Variabel dependennya yaitu peluang permintaan perumahan sederhana. Variabel dependen (variabel terikat) adalah variabel yang menjadi perhatian utama dalam sebuah penelitian. Variabel independen dalam penelitian ini yaitu harga rumah, pendapatan konsumen, fasilitas rumah, dan jenis pekerjaan.

\section{Definisi Operasional Variabel}

Definisi operasional variabel sebagai berikut :

a. Peluang pemilikan perumahan (Y) adalah kesempatan seseorang dalam membeli perumahan atau memiliki rumah Griya Pesona Asri yang dipengaruhi oleh variabel independen.

b. Harga rumah (X1) adalah harga mencerminkan biaya yang akan dibayarkan oleh seorang konsumen dalam membeli rumah Griya Pesona Asri di Kecamatan Sidoharjo Sragen. Harga merupakan faktor yang mendasar untuk seseorang dalam membeli rumah.

c. Pendapatan seseorang (X2) dalam hal ini yaitu pendapatan konsumen yang dinyatakan dalam pendapatan perbulan. Besar kecilnya pendapatan berpengaruh terhadap daya beli dalam pemilikan perumahan.

d. Fasilitas (X3) dalam penelitian ini digunakan variabel dummy yaitu memuaskan atau tidak memuaskan. Fasilitas yaitu segala perlengkapan fisik perumahan yang mampu memberikan kemudahan.

e. Jenis pekerjaan (X4) dalam penelitian ini digunakan variabel dummy yaitu pekerjaan tetap dan pekerjaan tidak tetap. Pekerjaan secara umum didefinisikan sebagai sebuah kegiatan aktif yang dilakukan oleh manusia.

\section{Metode Analisis Statistik Deskriptif}

Kegiatan menyimpulkan data mentah dalam jumlah yang besar sehingga hasilnya dapat ditafsirkan. (Mudrajad 2013).

Informasi yang diperoleh dari statistik diskriptif yaitu sebagai berikut :

1. Rata-rata atau mean yaitu hasil penjumlahan seluruh data dibagi dengan banyaknya data yang ada.

2. Median yaitu angka tengah yang diperoleh apabila data disusun dari nilai terendah hingga nilai tertinggi.

3. Modus atau mode yaitu merupakan nilai yang paling sering muncul, atau yang mempunyai frekuensi tinggi.

4. Standar deviasi adalah ukuran penyimpangan yang diperoleh dari akar kuadrat dari rata-rata jumlah kuadrat deviasi antara masing-masing nilai dengan rata-ratanya.

5. Nilai minimum adalah nilai terkecil dari keseluruhan data.

6. Nilai maksimum adalah nilai tertinggi dari keseluruh data.

\section{Model Linear Probability Model (LPM)}

Model probabilitas linear (Linear Probability Model sering disebut LPM) digunakan untuk menganalisis variabel dependen yang bersifat kategorik dan variabel independen yang bersifat non kategorik. (Win Wahyu Winarno 2015)

\section{Uji Hipotesis \\ Uji t Statistik}

Uji-t dilakukan untuk mengetahui apakah ada perbedaan dari nilai yang diperkiranakan dengan nilai hasil perhitungan statistik dan untuk menguji bagaimana pengaruh masing-masing variabel dependen terhadap variabel independen. Uji ini dilakukan dengan membandingkan $t$ tabel dan $\mathrm{t}$ statistik. Apabila $\mathrm{t}$ statistik $>\mathrm{t}$ tabel 
maka hasil signifikan atau menolak Ho dan bila $\mathrm{t}$ statistik < $\mathrm{t}$ tabel maka hasil tidak sigifikan atau gagal menolak Ho. Penelitian ini menggunakan derajat keyakinan (a) sebesar $5 \%$.

\section{Uji F}

Uji $f$ dilakukan untuk melihat bagaimanakah pengaruh semua variabel independen secara bersama-sama terhadap variabel dependen. Atau untuk menguji apakah model regresi signifikan atau tidak signifikan. Uji $f$ dapat dilakukan dengan membandingkan $F$ statistik dengan $F$ tabel. Apabila $\mathrm{F}$ statistik > $\mathrm{F}$ tabel maka hasil signifikan atau menolak $\mathrm{Ho}$ dan bila $\mathrm{F}$ statistik < $\mathrm{F}$ tabel maka hasil tidak signifikan atau gagal menolak Ho.

\section{Uji Koefisien Determinasi $\left(R^{2}\right)$ atau $R$ - Squared}

Uji Koefisien Determinasi $\left(R^{2}\right)$ atau $R$ Squared dilakukan untuk mengetahui baik atau tidaknya suatu regresi. Nilai $R^{2}$ mencerminkan seberapa besar variasi dari variabel dependen $(\mathrm{Y})$ dapat diterangkan oleh variabel independen $(X)$.

\section{Analisis Regresi}

Analisis regresi digunakan untuk mengetahui atau menguji kelayakan model dalam penelitian ini. Untuk menguji hipotesis maka digunakan analisis LPM (Linear Probability Model) dengan persamaan sebagai berikut :

$$
Y=\beta_{0}+\beta_{1} X_{1}+\beta_{2} X_{2}+\beta_{3} X_{3}+\beta_{4} X_{4}+e
$$

Keterangan :

$\mathrm{Y}=$ Peluang Pemilikan Perumahan (Nilai 1 jika memiliki rumah sederhana dan nilai 0 jika memiliki rumah selain sederhana)

X1 = Harga Rumah (Rupiah)

$\mathrm{X} 2$ = Pendapatan Konsumen (Rupiah/bulan) X3 = Fasilitas (Nilai 1 jika memuaskan dan nilai 0 jika tidak memuaskan)

X4 = Jenis Pekerjaan (Nilai 1 jika pekerjaan tetap dan nilai 0 jika pekerjaan tidak tetap) BO = Konstanta
B1 = Koefisen regresi Harga Rumah

B2 = Koefisen regresi Pendapatan Konsumen

B3 = Koefisen regresi Fasilitas

B4 = Koefisen regresi Jenis Pekerjaan

$\mathrm{e}=$ Variabel pengganggu (disturbance error)

\section{Analisis Nilai Peluang}

Nilai peluang yaitu nilai dengan membandingkan banyaknya titik sampel kejadian yang diinginkan dengan banyaknya anggota ruang sampel kejadian tersebut.

\section{Analisis Nilai Kritis}

Nilai kritis adalah nilai yang digunakan untuk membatasi suatu turunan. Nilai kritis ditentukan melalui :

$$
Y=a+b X_{i}=1 / 2(2)
$$

Nilai kritis digunakan untuk mengetahui seberapa besar variabel independen dalam mempengaruhi variabel dependen. (Vincent 1991)

\section{Analisis Efek Marginal}

Efek marginal yaitu digunakan untuk mengetahui perubahan probabilitas dari sebuah kejadian sebagai hasil dari satu unit perubahan pada nilai variabel independen manakala variabel lainnya konstan. (Gujarati 2015)

\section{Hasil Penelitian \\ Karakteristik Responden}

Jenis kelamin : berdasarkan hasil kuesioner menjelaskan bahwa persentasi responden terbesar yaitu jenis kelamin perempuan sebesar $52 \%$.

Usia : hasil kuesioner menjelaskan bahwa rata-rata warga yang mampu membeli rumah yaitu berumur 30-40 tahun sebesar $72 \%$.

Status material : berdasarkan hasil kuesioner bahwa persentase menunjukkan responden yang mampu membeli rumah yaitu yang berstatus sudah menikah sebesar $97 \%$.

Pendidikan terakhir : berdasarkan hasil kuesioner menunjukkan kepemilikan rumah berdasarkan pendidikan terakhir dapat 
disimpulkan bahwa warga yang mempunyai pendidikan tinggi memiliki daya beli yang lebih tinggi. Sedangkan warga yang berpendidikan SD dan SLTP lebih memilih bertempat tinggal di luar perumahan Griya Pesona Asri.

Status rumah : jumlah kepemilikan rumah berdasarkan rumah tangga di Kabupaten Sragen sebesar 247.230. Hal ini membuktikan bahwa sebanyak $0.025 \%$ penduduk Sragen bertempat tinggal di perumahan Griya Pesona Asri. Maka dapat disimpulkan bahwa kepemilikan di perumahan Griya Pesona Asri berstatus milik sendiri.

\section{Alasan Pemilikan Rumah}

Berdasarkan hasil kuesioner dapat diambil kesimpulan bahwa warga Griya Pesona Asri memiliki beberapa alasan dalam memutuskan pemilikan rumah di perumahan tersebut adalah sebagai berikut :

a. Harga perumahan : dengan harga yang terjangkau dibandingkan perumahan lain maka dapat menarik konsumen untuk membeli rumah. Oleh sebab itu harga merupakan faktor penting dalam pertimbangan membeli rumah.

b. Pendapatan konsumen : besar kecilnya pendapatan berpengaruh terhadap daya beli dalam pemilikan perumahan.Pengembang menawarkan beberapa tipe yang menjadi pertimbangan konsumen dalam memilih perumahan sesuai dengan pendapatan masing-masing.

c. Lokasi : lokasi perumahan megacu pada preferensi konsumen terhadap letak perumahan dan terkait dengan aksesbilititas.

d. Fasilitas : fasilitas merupakan segala perlengkapan fisik perumahan yang mampu memberikan kemudahan. Hal ini membuktikan bahwa fasilitas merupakan faktor pendukung dalam mempertimbangkan pembelin rumah.

\section{Faktor yang Mempengaruhi Pemilikan Rumah}

Adapun faktor-faktor yang mempengaruhi dalam pemilikan rumah antara lain harga rumah, pendapatan seseorang, fasilitas, dan jenis pekerjaan yang dijelaskan dibawah ini :

a. Harga perumahan : harga perumahan di Griya Pesona Asri tipe 45 sebesar 150-195 juta, tipe 60 sebesar 250 juta, sedangkan tipe 90 sebesar 310 juta, dan tipe 100 sebesar 325 juta. Berdasarkan hasil kuesioner menunjukkan bahwa rata-rata pemilikan rumah sebesar $\mathrm{Rp}$ 198.000.000,-. Hal ini membuktikan bahwa para responden lebih banyak memilih tipe perumahan sederhana.

b. Pendapatan seseorang : besar kecilnya pendapatan berpengaruh terhadap daya beli dalam pemilikan perumahan. Rata-rata pendapatan responden sebesar Rp 4.400.000,- per bulan. Dari rata-rata pendapatan tersebut, responden memiliki daya beli dalam pemilikan rumah.

c. Fasilitas : fasilitas dalam penelitian ini digunakan variabel dummy yaitu memuaskan atau tidak memuaskan. Berdasarkan data kuesioner menunjukkan bahwa fasilitas yang diberikan Griya Pesona Asri belum memuaskan, karena fasilitas tidak digunakan secara optimal.

d. Jenis pekerjaan : Jenis pekerjaan dalam penelitian ini digunakan variabel dummy yaitu pekerjaan tetap dan pekerjaan tidak tetap. Hasil data kuesioner menunjukkan persentase sebesar $90 \%$ warga perumahan Griya Pesona Asri memiliki pekerjaan tetap.

\section{Analisis Diskriptif}

- $\quad$ Statistik Deskriptif

Berdasarkan hasil analisis statistik deskriptif dijelaskan ringkasan statistik dari beberapa variabel. Melihat rata-rata atau 
mean harga perumahan yaitu sebesar 198.125 dengan standar deviasi sebesar 66.3714. Hal ini menunjukkan bahwa ratarata atau mean harga perumahan lebih besar daripada standar deviasi, artinya variabel harga perumahan menunjukkan simpangan data yang rendah.Serta standar deviasi yang tinggi menunjukkan bahwa sebaran/variabilitasnya tinggi. Pada variabel pendapatan konsumen menunjukkan ratarata atau mean sebesar 4.3625 dengan standar deviasi sebesar 1.6848. Maka menunjukkan bahwa rata-rata atau mean untuk pendapatan konsumen lebih besar dibandingkan standar deviasi. Hal ini menujukkan bahwa variabel pendapatan konsumen memiliki simpangan data yang rendah. Variabel fasilitas mempunyai ratarata atau mean sebesar 0.8125 dengan standar deviasi sebesar 0.3934. Hal ini membuktikan bahwa rata-rata atau mean lebih besar daripada standar deviasi. Demikian menunjukkan bahwa fasilitas mempunyai simpangan data yang rendah. Serta variabel mempunyai standar deviasi yang rendah maka membuktikan bahwa sebaran/variabilitas rendah. Pada variabel jenis pekerjaan rata-rata atau mean sebesar 0.90625 dan standar deviasi sebesar 0.2938. Maka rata-rata atau mean lebih besar daripada standar deviasi. Hal ini menunjukkan bahwa jenis pekerjaan mempunyai simpangan data yang rendah. Berdasarkan standar deviasi jenis pekerjaan menunjukkan standar deviasi yang rendah hal ini membuktikan bahwa sebaran/variabilitas yang rendah.
Nilai modus atau mode pada harga perumahan yaitu sebesar 150. Hal ini membuktikan bahwa banyak dari responden yang membeli perumahan dengan harga 150. Pada variabel pendapatan menjukkan modus atau modesebesar 5. Maka dapat disimpulkan bahwa kebanyakan responden mempunyai pendapatan 5 . Variabel fasilitas menunjukkan modus atau modesebesar 1 . Maka banyak dari responden yang mengisi data fasilitas dengan tingkat memuaskan. Sedangkan pada variabel jenis pekerjaan menunjukkan modus atau mode pada angka 1 yang mempunyai arti dari 64 responden mempunyai pekerjaan tetap.

Nilai minimum dan maksimum pada variabel harga perumahan menunjukkan 150 dan 325. Artinya, harga terendah dari 64 unit perumahan yaitu sebesar 150 sedangkan harga tertingginya sebesar 325. Variabel pendapatan konsumen ditunjukkan bahwa nilai minimum sebesar 2 dan 11.5. Hal ini menunjukkan bahwa pendapatan teresndah responden sebesar 2 sedangkan pendapatan tertinggi responden sebesar 11.5. Pada variabel fasilitas mempunyai nilai minimum sebesar 0 dan nilai maksimum 1. Artinya, untuk nilai minimum 0 berarti fasilitas yang disediakan tidak memuaskan dan nilai maksimum 1 untuk fasilitas yang memuaskan. Sedangkan pada variabel jenis pekerjaan memiliki nilai minimum sebesar 0 dan nilai maksimum sebesar 1. Hal ini membuktikan bahwa nilai minimum 0 ditunjukkan dengan pekerjaan tidak tetap dan nilai maksimum 1 menunjukkan pekerjaan tetap.

\section{Model Persamaan}

$$
Y=2.043233-0.006305 X 2-0.021075 X 2+0.004086 X 3+0.014760 X 4
$$

\section{Hasil R-Squared}

Berdasarkan dari hasil output regresi diatas besarnya pengaruh variabel independen terhadap variabel dependen sebesar 0.911367 yang menunjukkan bahwa variabel harga rumah, pendapatan, fasilitas, dan jenis pekerjaan mampu menjelaskan variasi total variabel dependen sebesar $91.13 \%$ dan sisanya $8.87 \%$ dijelaskan oleh variabel lain yang tidak dimasukkan dalam model penelitian ini. 
Uji t-Statistik

Harga Perumahan

Berdasarkan hasil olah data diatas menunjukkan bahwa t statistik untuk harga perumahan sebesar -21.94544 dengan menggunakan derajat keyakinan $(\alpha)$ sebesar $5 \%$ dan df 60 maka hasil t tabel sebesar 1.671. Melihat $t$ statistik rumah sebesar 21.94544 dan $t$ tabel sebesar 1.671 maka hasil $\mathrm{t}$ statistik $>\mathrm{t}$ tabel dan data regresi signifikan atau data menolak Ho.

Pendapatan Konsumen

Berdasarkan hasil olah data diatas menunjukkan bahwa $t$ statistik untuk pendapatan konsumen sebesar -1.739767 dengan menggunakan derajat keyakinan ( $\alpha$ ) sebesar $5 \%$ dan df 60 maka hasil $t$ tabel sebesar 1.671. Melihat t statistik pendapatan konsumen sebesar -1.739767 dan $t$ tabel sebesar 1.671 maka hasil t statistik > t tabel dan data regresi signifikan atau data menolak Ho.

\section{Fasilitas}

Berdasarkan hasil olah data diatas menunjukkan bahwa t statistik untuk fasilitas sebesar 0.086974 dengan menggunakan derajat keyakinan ( $\alpha$ ) sebesar $5 \%$ dan df 60 maka hasil $t$ tabel sebesar 1.671 . Melihat $t$ statistik fasilitas sebesar 0.086974 dan $t$ tabel sebesar 1.671 maka hasil t statistik < t tabel dan data regresi tidak signifikan atau data gagal menolak Ho.

Jenis Pekerjaan

Berdasarkan hasil olah data diatas menunjukkan bahwa $t$ statistik untuk jenis pekerjaan sebesar 0.232292 dengan menggunakan derajat keyakinan ( $\alpha$ ) sebesar
$5 \%$ dan $d f \quad 60$ maka hasil t tabel sebesar 1.671. Melihat $t$ jenis pekerjaan sebesar 0.232292 dan t tabel sebesar 1.671 maka hasil $\mathrm{t}$ statistik $<\mathrm{t}$ tabel dan data regresi tidak signifikan atau data gagal menolak Ho.

\section{Uji F-Statistik}

Berdasarkan hasil regresi diatas menunjukkan $F$ statistik sebesar 151.6658 dengan menggunakan derajat keyakinan (a) sebesar $5 \%$ dan df 60 . Maka $F$ tabel sebesar 2.76, melihat hasil tersebut dapat disimpulkan bawah $\mathrm{F}$ statistik $>\mathrm{F}$ tabel. Hal ini menandakan bahwa variabel independen (harga rumah, pendapatan konsumen, fasilitas, dan jenis pekerjaan) secara bersama-sama berpengaruh signifikan terhadap variabel dependen (peluang pemilikan rumah).

\section{- $\quad$ Analisis Nilai Peluang}

Nilai peluang dalam penelitian ini yaitu peluang seseorang dalam membeli perumahan sederhana yang dilihat dari harga perumahan, pendapatan konsumen, fasilitas ( 1 jika fasilitas memuaskan dan 0 jika fasilitas tidak memuaskan), dan jenis pekerjaan (1 jika pekerjaan tetap dan 0 jika pekerjaan tidak tetap). Analisis nilai peluang terdiri dari rata-rata, minimum, maksimum, dan mode pada setiap variabel independen dengan menggunakan batas sebesar 0.5. Apabila hasil output diatas 0.5 maka adanya peluang pemilikan rumah dan jika dibawah 0.5 maka tidak ada peluang pemilikan rumah. Hasil output dihitung berdasarkan persamaan sebagai berikut :

$$
Y=2.043233-0.006305 X 2-0.021075 X 2+0.004086 X 3+0.014760 X 4
$$


Hasil analisis nilai peluang jika fasilitas dan jenis pekerjaan bernilai 1 yaitu rata-rata harga rumah sebesar -1.249178 , pendapatan konsumen sebesar -0.091940 , fasilitas (bernilai 1 jika fasilitas memuaskan) yaitu sebesar 0.004086, jenis pekerjaan (bernilai 1 jika pekerjaan tetap) bernilai sebesar 0.014760 . Maka peluang pemilikan sebesar 0.720961. Dapat disimpulkan bahwa hasil output (Y) bernilai diatas 0.5 maka adanya nilai peluang pemilikan perumahan. Berdasarkan dari hasil diatas nilai minimum, maksimum dan mode atau modus tidak mempunyai nilai peluang karena hasil $Y$ di bawah 0.5.

Hasil analisis nilai peluang jika fasilitas dan jenis pekerjaan bernilai 0 yaitu rata-rata harga rumah sebesar -1.249178 , pendapatan konsumen sebesar -0.091940, fasilitas (bernilai 0 jika fasilitas tidak memuaskan) yaitu sebesar 0.000000 , jenis pekerjaan (bernilai 0 jika pekerjaan tidak tetap) bernilai sebesar 0.000000 . Maka peluang pemilikan sebesar 0.702115 . Dapat disimpulkan bahwa hasil output $(\mathrm{Y})$ bernilai diatas 0.5 dimana adanya nilai peluang pemilikan perumahan. Berdasarkan dari hasil diatas nilai minimum, maksimum dan mode atau modus tidak mempunyai nilai peluang karena hasil Y di bawah 0.5.

\section{- $\quad$ Analisis Nilai Kritis}

Berdasarkan hasil analisis nilai kritis dapat dijelaskan bahwa dengan harga perumahan seharga 403.368, konsumen hanya dapat membayar rumah sebesar 120.675. Sehingga konsumen hanya mampu membeli rumah tipe sederhana.

\section{- Analisis Efek Marginal}

Berdasarkan analisis efek marginal menunjukkan bahwa perumahan Griya Pesona Asri ditujukan untuk masyarakat yang berpendapatan sedang. Hal tersebut dibuktikan dari semakin besar pendapatan konsumen menunjukkan tingkat kepemilikan rumah sederhana semakin kecil.

\section{KESIMPULAN DAN IMPLIKASI Kesimpulan}

Berdasarkan latar belakang, landasan teori, hasil pengujian, dan analisis hipotesis masing-masing variabel. Dapat disimpulkan sebagai berikut :

1. Latar belakang masyarakat dalam membeli perumahan sederhana di Griya Pesona Asri yaitu antara lain harga rumah yang sesuai dengan anggaran konsumen, pengembang menawarkan beberapa tipe perumahan yang sesuai dengan pendapatan konsumen, serta lokasi yang dekat dengan akses jalan utama, dan mempunyai fasilitas seperti tempat ibadah serta ruko yang menyediakan kebutuhan primer dan sekunder.

2. Harga perumahan dan pendapatan konsumen berpengaruh signifikan. Semakin tinggi harga perumahan maka semakin rendah peluang pemilikan perumahan. Ketika adanya kenaikan pendapatan mengakibatkan peningkatan peluang pemilikan rumah terutama perumahan tipe selain sederhana. Hal ini menyebabkan penurunan permintaan perumahan sederhana.

3. Fasilitas dan jenis pekerjaan tidak mempunyai pengaruh yang signifikan terhadap peluang pemilikan perumahan sederhana atau selain sederhana. Hal ini bisa disebabkan warga Griya Pesona Asri ketika membeli perumahan bukan hanya mempertimbangkan fasilitas, tetapi juga selera mereka. Serta jenis pekerjaan dalam penelitian ini ditentukan oleh dummy (1 untuk pekerjaan tetap dan 0 untuk pekerjaan tidak tetap).

4. Peluang pemilikan rumah sederhana atau selain sederhana dijelaskan pada nilai peluang berdasarkan rata-rata faktor variabel independen yaitu harga perumahan, pendapatan konsumen, fasilitas, dan jenis pekerjaan sebesar 
0.720961 (apabila fasilitas dan jenis pekerjaan bernilai 1) dan 0.702115 (apabila fasilitas dan jenis pekerjaan bernilai 0 ). Nilai peluang rata-rata variabel independen berada di atas 0.5. Sedangkan berdasarkan nilai minimum, maksimum, dan modus dibawah 0.5.

5. Nilai kritis harga perumahan Griya Pesona Asri sebesar 403.368 dan nilai kritis untuk pendapatan utama konsumen sebesar 120.675. Hal ini menjelaskan bahwa konsumen hanya mampu membeli perumahan sederhana.

6. Berdasarkan analisis efek marginal menunjukkan bahwa perumahan Griya Pesona Asri ditujukan untuk masyarakat yang berpendapatan sedang. Hal tersebut dibuktikan dari semakin besar pendapatan konsumen menunjukkan tingkat kepemilikan rumah sederhana semakin kecil.

\section{Implikasi}

1. Bagi Pemerintah

Seiring dengan adanya peningkatan penduduk dan banyaknya permintaan perumahan, terutama perumahan sederhana. Maka pemerintah khususnya pemerintah Sragen lebih banyak memperbanyak perumahan.

2. Bagi Pengembang

Untuk pengembang lebih memperbanyak perumahan, hal ini dibuktikan karena peluang pemilikan rumah cukup besar. Serta jenis pekerjaan dan fasilitas tidak mempengaruhi secara signifikan terhadap peluang pemilikan rumah di Griya Pesona Asri Kecamatan Sidoharjo Sragen Jawa Tengah. Jenis pekerjaan tidak berpengaruh signifikan bisa disebabkan beberapa faktor salah satunya yaitu mempunyai pekerjaan sampingan dengan pendapatan yang lebih tinggi daripada yang mempunyai pekerjaan utama dengan pendapatan rendah. Serta pada faktor fasilitas tidak berpengaruh signifikan, hal ini bisa disebabkan warga Griya Pesona Asri ketika membeli perumahan bukan hanya mempertimbangkan fasilitas, tetapi juga selera mereka. Maka dari itu pengembang lebih memperhatikan harga perumahan dan pendapatan konsumen dibandingkan jenis pekerjaan konsumen dan fasilitas yang diberikan.

\section{DAFTAR PUSTAKA}

Badan Pusat Statistik, Indeks Pertumbuhan Penduduk tahun 2012-2013. Badan Pusat Statistik Sragen.

Badan Pusat Statistik, Sragen Dalam Angka 2014. Badan Pusat Statistik Sragen.

Budi, Mulyo. (2009), "Analisis Permintaan Rumah Sederhana di Kota Semarang", Jurnal Bisnis dan Ekonomi, Hal 126-139.

Dengah, Stefandy dkk. (2014), "Analisis Pengaruh Pendapatan Perkapita dan Jumlah Penduduk Terhadap Permintaan Perumahan Kota Manado Tahun 2003-2012", Jurnal Berkala IImiah Efisiensi, Volume 14, No 3.

Fair dan Case (2002), Prinsip-Prinsip Ekonomi Mikro. PT Ikrar Mandiri Abadi, Jakarta.

Gaspersz, Vincent (1991), Ekonometri Terapan. Tarsito, Bandung.

Gujarati, Damodar N (2015), Dasar-dasar Ekonometrika. Salemba Empat, Jakarta

Mahardini, Ismi dan Nenik Woyanti. (2012), "Analisis Pengaruh Harga, Pendapatan, Lokasi, dan Fasilitas Terhadap Permintaan Rumah Sederhana", Jurnal Ekonomi Diponegoro, Volume 1, No 1.

Mankiw, Gregory (2003), Pengantar Ekonomi Mikro. Salemba Empat, Jakarta.

Republik Indonesia, Undang-Undang Nomor No 4 Tahun 1992 tentang Perumahan dan Pemukiman. 
Setiawan, Ikhsan M. (2004), "Analisis

Kepuasan Konsumen dalam

Pemilihan Perumahan Sederhana", Neutron, Vol. 4, No 2.

Sugiyono (2014), Metode Penelitian Kuantitatif Kualitatif dan $R \& D$. Alfabeta, Bandung.

Winarno, Win Wahyu (2015), Analisa Ekonometrika dan Statistika dengan Eviews. UPP STIM YKPN, Yogyakarta. 